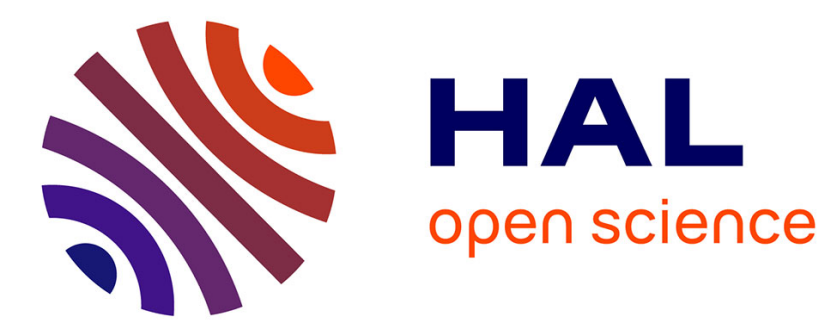

\title{
Economic impacts of the ASEAN single aviation market: focus on Cambodia, Laos, Myanmar, The Philippines and Vietnam
}

Isabelle Laplace, Nathalie Lenoir, Chantal Roucolle

\section{- To cite this version:}

Isabelle Laplace, Nathalie Lenoir, Chantal Roucolle. Economic impacts of the ASEAN single aviation market: focus on Cambodia, Laos, Myanmar, The Philippines and Vietnam. Asia Pacific Business Review, 2019, 25 (5), pp.656-682. 10.1080/13602381.2019.1652979 . hal-02297335

\section{HAL Id: hal-02297335 \\ https://hal-enac.archives-ouvertes.fr/hal-02297335}

Submitted on 26 Sep 2019

HAL is a multi-disciplinary open access archive for the deposit and dissemination of scientific research documents, whether they are published or not. The documents may come from teaching and research institutions in France or abroad, or from public or private research centers.
L'archive ouverte pluridisciplinaire HAL, est destinée au dépôt et à la diffusion de documents scientifiques de niveau recherche, publiés ou non, émanant des établissements d'enseignement et de recherche français ou étrangers, des laboratoires publics ou privés. 


\section{Economic impacts of the ASEAN single aviation market: focus on Cambodia, Laos, Myanmar, The Philippines and Vietnam}

Isabelle Laplace, Ecole Nationale de l'Aviation Civile (ENAC), University of Toulouse (France).

Nathalie Lenoir, Ecole Nationale de l'Aviation Civile (ENAC), University of Toulouse (France).

Chantal Roucolle, Ecole Nationale de l'Aviation Civile (ENAC), University of Toulouse (France).

Correspondence : Ecole nationale de l'Aviation Civile, 7, avenue Edouard Belin, CS 54005, 31055 Toulouse Cedex 4, FRANCE

Email: isabelle.laplace@enac.fr

\section{Authors information}

\section{$\underline{\text { Isabelle Laplace }}$}

Dr. Isabelle Laplace is PhD holder in economics and is currently the Head of the Air Transport Sustainable Growth Research Program at ENAC. Her expertise concerns the economic aspects of the air transport market in terms of passenger demand, airline behaviour, airport strategies, airport capacity, air transport liberalisation, energetic transition, innovation strategies, door-to-door travel and intermodality features between air other transport modes.

\section{$\underline{\text { Nathalie Lenoir }}$}

Dr. Nathalie Lenoir is Professor of Economics and Coordinator of Economics courses at ENAC. Her research interest include congestion pricing, airport slots, competition and intermodality in the air transport, market regulations, airport strategies and multimodal travel demand.

\section{Chantal Roucolle}

Dr. Chantal Roucolle is professor of Economics at ENAC. She specializes on applied econometrics. She develops empirical researches related to air transport economics. Her main focus is related to airlines' behaviour on imperfect markets: pricing, supply of capacities, network expansion, innovation. 


\begin{abstract}
Since 2004, the Association of South East Asian Nations (ASEAN) has decided to move towards liberalization of air transport inside the region as well as outside by signing multilateral agreements with other countries. In this work, we focus on the economic impact of liberalization. We show that by liberalizing up to the 5th freedom right, given the expectation in tourism development, national GDP is expected to increase yearly from $1 \%$ (Cambodia) to $6.1 \%$ (The Philippines). Regarding partner states involved in multilateral agreements, the case of China shows that ASEAN airlines can face possible competition distortion as a result.
\end{abstract}

Keywords; air transport; ASEAN; competition distortion; economic impact estimation; liberalization; market regulation;

\title{
Introduction
}

Air transport in South East Asia has been historically regulated on the basis of bilateral agreements which imposed restrictions on the operations of all carriers. The idea of liberalizing the air travel sector in the region goes back to the ASEAN (Association of South East Asian Nations) leaders' summit held in Bangkok in 1995. In 2004, the 10th air transport ministers' meeting in Phnom Penh decided upon an "Action Plan for ASEAN Air Transport Integration and Liberalization 2005-2015" (10th ASEAN Transport Ministers Meeting 2004). The objective was to establish a single aviation market by 2015. Since then, while not all of the countries have reached the same level of ratification, they have all made steps towards greater liberalization. The first target which has been reached was to open $3^{\text {rd }}, 4^{\text {th }}$ and $5^{\text {th }}$ freedom rights inside the ASEAN region for ASEAN carriers by 2015. With this first step, also named ASEAN open skies, ASEAN airlines are still only allowed to fly to and from their home country to neighbouring ASEAN countries but with greater freedom (all entry points are granted, there are no more frequency and capacity constraints). They are also granted $5^{\text {th }}$ freedom rights to extend flights beyond their home country.

This work starts with a literature review of the economic impacts of previous air transport liberalization experiences. We then explain the specific econometric method developed to assess the impact of liberalization on GDP in the five considered ASEAN countries, and present the results in terms of regional GDP growth due to liberalisation. In a third part, we look at the impact of a multilateral agreements with a third country on ASEAN carriers. We highlight possible competition distortion in air transport on international markets with the example of the multilateral agreement between ASEAN and China. 
Considering those results, we conclude with some recommendations in order to anticipate future traffic growth and potential competition unbalances.

The work presented here has been undertaken in the scope of the ASEAN Air Transport Integration Project (AATIP), supporting the making of the ASEAN Single Aviation Market (Laplace et al. 2015). The objective of AATIP was to facilitate the development of ASEAN frameworks to strengthen institutional capacities in order to achieve a safe, secure and sustainable ASEAN Single Aviation Market (ASAM). AATIP made some recommendations in terms of harmonisation of regulations in the ASEAN area with high regulatory standards.

\section{Literature review on previous air transport liberalisation experiences}

In previous liberalisation experiences (e.g. USA (Goetz and Vowles 2009), EU-Africa (Njoya, Christidis, and Nikitas 2018), US-Carribean (Warnock-Smith and Morrell 2008), EU-Morocco (Dobruszkes and Mondou 2013)), it has been observed that air transport liberalization led to higher air traffic volumes. In a deregulated environment, airlines have to adapt their strategies in response to new possibilities and a stronger competition illustrated by an increased number of operating carriers at the route level (Warnock-Smith and Morrell 2008; Burghouwt and de Wit 2015; Olariaga and Zea 2018). They can compete within their existing network by operating more frequencies (Njoya, Christidis, and Nikitas 2018, 2018) or expand and optimise their network (FU, OUM, and ZHANG 2010; Jankiewicz and Huderek-Glapska 2016) and offer more destinations. They strive to reduce ticket prices and increase the quality of their services (Abate 2016; Goetz and Vowles 2009; Njoya, Christidis, and Nikitas 2018). Deregulation is hence a recognized driver of traffic and network growth (Jankiewicz and Huderek-Glapska 2016) and is recognised as bringing positive impacts on countries' economies (FU, OUM, and ZHANG 2010). For instance, INterVISTAS (InterVISTAS-ga 2006) models the liberalisation effects and shows that the air traffic increase in air traffic generates significant employment benefits. In a 2016 working paper, ICAO also concludes that liberalization leads positive externalities to the overall economy including GDP growth and employment opportunities.

These positive impacts, however, can be less than expected if airlines face barriers to entry at airports. When studying the impacts of air transport liberalization on airline competition in Europe, Dobruszkes (2009) stresses that "the saturation of a number of European airports is a strong barrier to the entry of new carriers or to the extension of existing ones". Oliveira, Lohmann, and Costa (2016) also highlight the combined role of airline activity concentration and airport congestion in generating entry barriers for airlines. Other limitations to the expected positive economic impacts can come from possible competition distortion between airlines if the completion level of the liberalization process is different according to countries. Multilateral liberalisation agreements are likely to have more positive economic implications than bilateral agreements (IATA 2007). IATA explains that if airlines do not have the full commercial freedom to restructure capacity in response, this restricts their ability to achieve a 
sustainable level of return on investment and cost to all stakeholders in the aviation industry at a long-term and as a consequence limit the expected positive economic impacts.

So far, there are only few studies that estimate the economic impact of air transport liberalization for the ASEAN countries. ECORYS (2012) only addresses economic impacts of the ASEAN air transport liberalisation (in terms of contribution to GDP, employment growth or tourism growth) due to expected air traffic increase between ASEAN member states but not consider the traffic with non-ASEAN member states. InterVISTAS-ga (2006) focused on the impacts of air transport liberalization at a worldwide level but was not able to provide reliable results for developing countries such as ASEAN member states, due to missing data. The impacts of the air liberalization agreements both on the economic development inside ASEAN and on the organisation of air transport have not yet been studied.

Our paper aims to fill this gap in the literature by first estimating, by local and regional GDP impacts of liberalization for five ASEAN countries: Cambodia, Lao PDR, Myanmar, the Philippines and Vietnam. Then, we study impacts of a multilateral agreement with third country on the air transport organisation, by considering the ASEAN-China multilateral agreement and by analysing the existence of barriers to entry.

\section{Quantifying the economic impacts of the ASEAN liberalization}

\section{Methodology}

We develop an econometric model to quantify the economic impacts of the air transport liberalization up to the $5^{\text {th }}$ freedom right in the ASEAN countries. The analysis focuses on five countries, Cambodia, Lao PDR, Myanmar, the Philippines and Vietnam, and is conducted independently for each of them. We implement a two-stage methodology.

(1) First, we estimate a model which expresses, for each country, the relationship between economic development and air traffic, in terms of number of passengers. The level of regional GDP is used as a proxy for economic development in airport areas. The number of air passengers is the measure of air transport performance. The model is estimated based on observation during the period 2004-2013.

(2) Then, based on air passenger growth scenarios, between 2014 and 2020, we use this econometric model to forecast the potential impact on GDP growth up to 2020 .

We conduct the analysis at the regional level, focusing on regions that include at least one airport. In order to isolate the GDP growth due to the increase in passengers from its growth due to other characteristics of the region, or to socio-economic chocks which impact independently all the regions, we include in the estimated model different controls variables. In particular, the period of observation includes the world financial crisis, 
which has drastically affected the performance of air transport worldwide. ASEAN air transport market, as others markets, suffered from this crisis. Thus, we introduce in the model some controls for this specific chock.

We give measures of GDP growth by region and by country, as a consequence of the expected increase in air transport passengers. Regional GDP should always be preferred as the improvement in economic performances should be better appreciated locally, in area where air traffic is concentrated. Nonetheless, we will provide impacts at the national level after some aggregation of regional effects. Additionally, the sense of causality between air transport performances and economic growth is uncertain. This issue is taken into consideration with the use of an instrumental variable estimation method that requires two stages.

\section{Data}

We use data collected directly from the states under consideration, complemented by other aviation and non aviation public data. The data provided by the states are yearly data for the period 2004-2020. They are related to air transport performances and socioeconomic indicators for the period 2004-2013 and forecast of some of the above measures for the period 2014-2020.

Air transport data provided by national civil aviation authorities includes yearly domestic and international passengers per airport. We use the number of passengers as a proxy for air transport performances. The total number of passengers at airport level is a relevant indicator to address the question of impact of air traffic on regional economic performances. The existence of uncertainty regarding the sense of causality between air transport performance and economic activity leads to the use of instrumental variables to correct the potential endogeneity. In addition, the relative importance of international and domestic passengers is considered as a proxy for air transport structure. We argue that air transport structure affects the level of airports' performance. We use the air transport structure, as explained later on, as an instrumental variable in the estimated model. Wen turning to the forecast up to 2020, we assume that air transport structure will remain constant over the period 2014-2020. Although restrictive, this assumption is necessary to produce consistent air transport forecast up to 2020, in the absence of information on the evolution of individual airport traffic structure beyond the period of observation.

National ministries of tourism provided yearly tourism activity index and yearly forecasts until 2020 of international number of tourists. We use this information for two different purposes. Firstly, in the estimation process, the yearly index is an instrumental variable for the treatment of air passenger endogeneity. This choice is justified by the low level of tourism contribution to GDP in ASEAN countries. The contribution of tourism activity to GDP is in 2013, quite close and low for Lao PDR, the Philippines and Vietnam (between 4 and 4.6\%). It is even lower for Myanmar, accounting for 1.6\% of GDP only. Thus, we consider that tourism does not affect GDP but should influence the number of passengers. Secondly, during the forecast process, we use the forecasted number of 
tourists to recover the expected number of passengers.

In addition, we use GDP and population as socio-economic indicators. GDP comes from the World Bank database where the information is delivered at a national level. Our objective is to estimate the impact of the air traffic development at the regional level. GDP is the variable to explain and this implies to observe it at the regional level. The regional GDP information is unavailable and we make the strong assumption that regional GDP is proportional to the number of inhabitants in the region.

For all countries but Cambodia, we were able to collect population information, at city or regional level, on the cities websites. Cambodian population is collected at the national level. No historic evolution is available for the population data: the information is collected for a unique year. We assume stability of the regional level of population over the full period of analysis. This is a strong assumption as between 2003 and 2020 we should expect some regions, in particular the highest economic developed areas, to see their number of inhabitants to increase more than other less dynamic regions. Moreover, the overall number of inhabitants is increasing. The assumption of stability should lead to underestimate the effects.

\section{First stage results: estimation of the impact of air traffic on GDP}

We express a linear relationship between the yearly regional GDP and the yearly number of passengers at airports. The regional impacts of liberalization depend on the socioeconomic characteristics of the region at stake. We argue that any change in the number of passengers might have different impacts on economic growth depending on the airport characteristics. Socio-economic differences between regional areas are controlled for thanks to airport fixed effects. Moreover, whether the airport is domestic or international might be of particular importance. We introduce a dummy variable to distinguish between international and domestic airports. Yearly fixed effects are included when necessary to take into account the non-measurable economic shocks linked with the world financial crisis. However, the relevant yearly fixed effects vary according to the country, as we will see in the forthcoming estimations.

The relationship between regional GDP and the number of passengers arriving or departing in the region is expressed as:

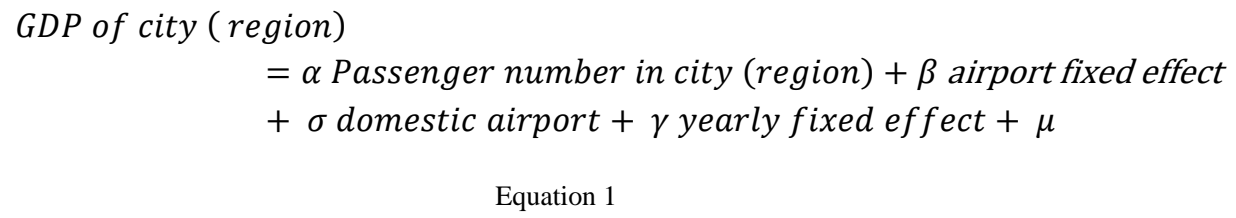

where $\alpha, \beta, \sigma$ and $\gamma$ are the parameters to be estimated and $\mu$ is the error of the model. $\mu$ includes all the factors also affecting the level of GDP but which cannot be observed. In order to control for the temporal effect, the estimation is performed using the differenceby-difference methodology. The variables included in the model are therefore expressed as yearly changes. 
There is uncertainty regarding the sense of causality between the GDP and the number of passengers. To control for the sense of causality and the consequent endogeneity issue, we use the usual instrumental variable method. As explained previously, we use the percentage of international air passengers as a first instrument for the number of passengers. This percentage interprets as the structure of air transport activity. For international airports, we set the share of international passengers equal to its yearly level over the period 2004-2013. For domestic airports, the share of international passengers equals zero. We argue that air transport structure has no direct link with GDP, although its relationship with the number of passengers at airport level is non-ambiguous: we observe that the number of passengers in international airport is always higher than the number of passengers in domestic airport. This justify the use of this variable as an instrument.

The second instrument is the number of tourists, used as a proxy for tourism activity. This information is available at the national level. As explained in the data section, the low level of tourism contribution to GDP in the different countries justify the choice of this variable as an instrument. The number of tourists directly impacts the number of passengers, but does have a direct effect on GDP.

The estimation using instrumental variables does not generally require the specification of the relationship between the endogenous variable and it instruments. However, in our particular case, the finale objective is to provide forecast of DGP growth following traffic growth up to 2020. No forecast of air passengers is available, but the States provided tourists forecasts. Thus, we need to use the forecasted number of tourists to recover the forecasted number of passengers. This necessitates to specify and to estimate the relationship between the number of passengers and the number of tourists.

The preliminary step in our estimation process consists in estimating the regional number of passengers on the above-defined instruments. The instruments have to be correlated with the number of passengers, but uncorrelated with the error of the first model in Equation 1. The instruments are the yearly number of tourists, the percentage of international air passengers into the corresponding region, and all the other exogenous variables of the model in Equation 1, regional (or airport) and yearly fixed effects, domestic or international airport.

Then we can express the regional number of passengers as:

Passenger number in city (region)

$=\delta$ tourist number $+\eta$ percentage of international passengers $+v$ domestic airport

$+\tau$ regional fixed effect $+v$ yearly fixed effect $+\psi$

Equation 2

where $\delta, \eta, v, \tau$ and $v$ are the parameters to estimate, and $\psi$ is the error of the model. As in the previous estimation, the model is estimated using difference by difference estimation.

The two equations 1 and 2 are estimated using the model procedure in SAS where we 
specified the 3SLS method which takes into account both endogeneity of some of the regressors and cross-equation correlation of the errors. This methodology is applied independently for four countries: Lao PDR, Myanmar, The Philippines, and Vietnam. For the fifth one, Cambodia, due to data constraints, the model is adapted. We estimate it, still using a 3SLS method for the Equation 1 and 2, but at airport level rather than regional level. ${ }^{1}$

Thanks to the estimated parameters, we can measure GDP growth for the period 20142020 linked with airport traffic forecasts, thanks to tourism development forecasts on the same period. The process is the following: we use the tourist forecast on the period 20142020 and, first, use Equation 2 to calculate the increase in passenger number. Then we use Equation 1 to measure the impact on GDP.

The main limitation of the above described method lies in the lack of information regarding drivers of GDP other than passenger numbers. This could lead to marginally overestimating the impacts even though the instrumental variable method partially fixes this issue of missing variables. However, the relative impact on the different regions and the comparison of impacts between countries remain relevant since the methodology respects the regional specificities of each country. Additionally, the provided forecasts by country (regarding the growth of the number of tourists or the number of passengers to 2020) intensify the marginal overestimation phenomenon as the rate of growth before and after 2013 increases a lot.

\section{Second stage results: Forecasts of the impact of air traffic on GDP}

Forecasting the impact of air traffic on GDP up to 2020 requires including forecasts of the number of air passengers in Equation 1. Based on tourist predictions up to 2020, a preliminary step consists in using the relationship between passengers and the number of tourists (Equation 2) to assess the impact of the increase in the number of tourists on the number of air passengers. Then, the impacts on GDP are estimated by introducing the air passenger forecasts in Equation 1.

The forecasts are implemented under the assumption that the share of international passengers remains constant for the period of prediction. This amounts to assuming that the structure of air traffic remains constant over the period of prediction. For international airport and from 2014 to 2020 , we set the share of international passengers equal to its average level on the observed period 2004-2013. For domestic airport, we keep the share of international passengers equal to zero, assuming here that these airports will remain domestic airport up to 2020. This is one of the main limits of the model, as the deregulation should enhance international traffic share at international airports.

Finally, for robustness imperatives, we use the Monte Carlo technique of simulation available in the SAS model procedure. It consists in assessing the different potential economic impacts when the values of the estimated parameters of the econometric model are modified inside their respective confident intervals. Therefore, we obtain some

\footnotetext{
${ }^{1}$ The results of the estimation are available in the end notes.
} 
distributions of the regional impacts rather than single values. The results reported in Table 1 are the means of these distributions.

Table 1 presents air traffic impact on GDP forecasted up to 2020. Figures represent the average yearly GDP growth over the period 2014 and 2020.

Table 1 ASEAN Single Aviation Market impact on GDP. Estimated yearly GDP growth for the period 2014 to 2020.

\begin{tabular}{lcrrr}
\hline & $\begin{array}{l}\text { Regions with } \\
\text { domestic airports } \\
\text { only }\end{array}$ & $\begin{array}{l}\text { Region with } \\
\text { international } \\
\text { airports only }\end{array}$ & $\begin{array}{l}\text { Regions with } \\
\text { domestic and } \\
\text { international } \\
\text { airports }\end{array}$ & Country \\
\hline Lao PDR & $+13.5 \%$ & $+6.2 \%$ & & $+2.1 \%$ \\
Myanmar & $+1.5 \%$ & $+2.5 \%$ & $+1.0 \%$ & $+1.2 \%$ \\
The Philippines & $+7.2 \%$ & $+6.2 \%$ & $+5.6 \%$ & $+6.1 \%$ \\
Vietnam & $+6.2 \%$ & $+6.1 \%$ & $+3.2 \%$ & $+2.9 \%$ \\
\hline
\end{tabular}

Table 2 ASEAN Single Aviation Market impact on Cambodian GDP. Estimated yearly regional GDP growth for Cambodian regions for the period 2014 and 2020.

\begin{tabular}{llll}
\hline & $\begin{array}{l}\text { Phnom Penh } \\
\text { regional GDP }\end{array}$ & $\begin{array}{l}\text { Siem Reap } \\
\text { regional GDP }\end{array}$ & Country \\
\hline Cambodia & $+4.9 \%$ & $+18.4 \%$ & $+1.0 \%$ \\
\hline
\end{tabular}

The forecasted GDP growth at a country level, between 2014 and 2020, differs a lot between countries. The Philippines will benefit from the highest effect with an annual expected increase of $6.1 \%$ of its GDP. The effect is expected to be around 2-3\% yearly for Lao PDR and Vietnam. Finally, the impact on GDP should be the lowest, but still positive for Myanmar and Vietnam: $+1.2 \%$ and $+1 \%$ respectively.

At a regional level, it is particularly interesting to observe that for all countries, except Myanmar, the highest GDP growth should be in regions with domestic airports only. In other words, despite the fact that the air transport liberalization only concerns international airports, domestic airports should also benefit from traffic increase at international airports, which will play the role of national hubs. However, the strongest expected GDP growth in regions where only domestic airports are located does not mean that these regions will bring the highest contribution to the national GDP. The GDP levels in these regions are generally lower than in regions with international airports where we observe, in general, the largest industrial and/or tourism development.

The expected increase in national GDP strongly relates to two main effects: the current contribution of the tourism activity on national GDP and the forecasted tourism activity growth expected by each country up to $2020 .^{2}$ Countries with an important tourism

\footnotetext{
${ }^{2}$ We argue that Tourism has not direct impact on GDP but affect it through air passengers' number. However, we analyze the effect on GDP thanks the observation and forecasts on tourist numbers
} 
activity such as the Philippines and Vietnam should benefit from the higher yearly GDP growth over the period ( $+6.1 \%$ and $+2.9 \%$ respectively). The expected economic growth due to the ASEAN air transport liberalization is particularly important for the Philippines already which welcomed 5\% of the total tourists in the ASEAN region in 2013 (Source: Philippines Statistics Authority) and forecasts a tourism yearly growth of $6.75 \%$ by 2020 . The expected GDP growth of Vietnam following the liberalization should also be mainly due to its tourism activity. Vietnam is ranked $5^{\text {th }}$ in ASEAN in terms of number of yearly tourists, with an expected yearly growth of 6\% by 2020 (source Vietnam Tourism Ministry). Moreover, the direct contribution of travel and tourism to the country's GDP represents $4.6 \%$ in 2013 which is slightly higher than the average tourism contribution to GDP in ASEAN (4.2\%).

The explanation of the moderate expected economic growth for Lao PDR $(+2.1 \%$ yearly increase up to 2020) is related to the moderate tourism activity growth expected by 2020 ( $+3 \%$ yearly increase in numbers of tourists) combined with the low tourism activity in 2013 (Source Myanmar tourism Ministry).

In Cambodia, the economic impact of the air transport liberalization in terms of GDP should be five times higher in Siem Reap than in Phnom Penh. The explanation of this large difference comes from the very important tourist activity in the Siem Reap region. In 2013, the number of tourist in the Siem Reap province represented 53.1\% of the total number of tourists in the country. Air passengers at Siem Reap airport are, for most of them, tourists who stay for several days in the region and spend money visiting the Angkor monuments and staying at hotels, restaurants, shops. An increase in activity at Siem Reap airport promises important economic impacts for the region.

We show the positive impact of liberalization on regional economies. The expected passenger increase will boost the economic development in ASEAN market. We show that the impact is heterogeneous among and within ASEAN countries.

However, capacity constraints at some airports could mitigate these traffic forecasts and the expected positive economic impacts. Laplace and Malavolti (2016) illustrate this problem by considering Soekarno-Hatta airport in Indonesia. Their analysis shows that the saturation of the main international airports in Indonesia will lead to a potential loss of air traffic in this country. Soekarno-Hatta airport will lose 49 million passengers by 2020 if the traffic is not diverted to other places. These figures are computed using Indonesian traffic forecast up to 2020. Authors obtain that 82 Million passengers more are expected at Soekarno-Hatta by 2020. Thirty-three million out of these 82 million passengers could be diverted to other Indonesian international airports which have some spare capacity. However, all the expected traffic will not be handled.

\section{Liberalization with a third party: the ASEAN-China multilateral agreement}

The organisation and development of air transport inside ASEAN and its impact on the economies of the region also depends on relationships with other countries. In this respect, 
the case of the agreement between ASEAN and China gives some hints as to what those impacts could be in the future, and about the risks involved. The EU-ASEAN Comprehensive Air Transport Agreement (CATA) which is currently under negotiation will also give new opportunities to ASEAN and non-ASEAN air carriers.

\section{The air service agreement with China}

At the beginning of 2010, ASEAN and China established the ASEAN-China Free Trade Area (ACFTA). At the end of the same year, ASEAN signed an air service agreement with China. The reason behind the first initiative lies mainly in the importance of commercial links between China and the countries of ASEAN. Trade between them grew at an average annual rate of 46\% during the period 2000-2010 (IMF 2018). In 2008, ASEAN represented 9\% of all imports and exports of China in value (US\$ billions, (Ministry of commerce, People's Republic of China 2018)). It was even more in 2013, with $10.66 \%$. On the ASEAN side, trade (imports and exports) with China (including Hong Kong) represented $18.5 \%$ of all ASEAN external trade in 2010 (US\$ billions, (IMF 2018)). The strength and growth of commercial links between ASEAN and China are therefore an important factor in explaining the willingness to open the markets to trade and lower the trade barriers.

A major determinant of growing air transport between ASEAN and China appears to be tourism: tourism arrivals from China grew by 86\% from 3.93 million in 2007 to 7.32 million in 2011 (ASEAN 2018). Even before signing the agreement, the traffic of ASEAN with China (including Hong Kong) already represented 23,9\% of all international seats into/out of ASEAN ('OAG Analyser' 2008). The importance of this traffic flow has pushed the authorities to alleviate the constraints and give more freedom to the airlines of both regions: less capacity constraints and more possibilities to open new routes.

What is the nature of this new air service agreement? In the first protocol of this agreement, 3rd and 4th freedom rights are liberalized on both sides, with the exception of Hong Kong, Macao and Taiwan (points excluded by China). This enables ASEAN carriers to go from their own country to anywhere in China, as long as the airport is not saturated. Chinese carriers are allowed to go from anywhere in China to any point in ASEAN. The first protocol had now been ratified by China and all ASEAN countries (ASEAN 2017) and is already in force.

A second protocol, concerning the 5th freedom has been signed in November 2014, but it is not expected to lead to any significant result because only secondary cities are concerned on both sides, with a capacity limit. It has been ratified by China and all ASEAN countries except Indonesia and Brunei (ASEAN 2017). It came into force in September 2015.

The first protocol appears to give ASEAN airlines some immediate benefits, by opening up any point in China (except the three excluded points). The protocol also opened the ASEAN market to Chinese airlines. It is to be remarked that slot restrictions at major airports can limit access on both sides: difficulties for ASEAN airlines to reach main 
cities in China (Beijing, Shanghai and others), and problems for Chinese airlines to reach main cities in ASEAN where some capital airports are congested.

These protocols lead to unbalances in traffic rights, given the fact that Chinese carriers can start from anywhere in China to go to anywhere in ASEAN, and have thus access to a larger market than ASEAN carriers. Those can only start from their ASEAN country of origin, because the process of liberalization inside ASEAN is not yet complete. This could lead to an unbalance in market shares between Chinese and ASEAN Airlines, and this is what we investigate thereafter.

\section{Methodology : Analysis of seats and market shares between ASEAN and China}

We analyse here the evolution of traffic between ASEAN and China in order to assess the impact of the multilateral treaty.

\section{i) Global overview}

The international traffic to and from ASEAN has developed strongly in the last decade with $80 \%$ more seats supplied in 2015 than in $2006 .{ }^{3}$ The strongest growth was between 2010 and 2015 with $49 \%$ more seats supplied. This growth is quite homogenous over the years between ASEAN and non-ASEAN airlines, which supply a balanced total number of seats each year, as shown in Fig 1.

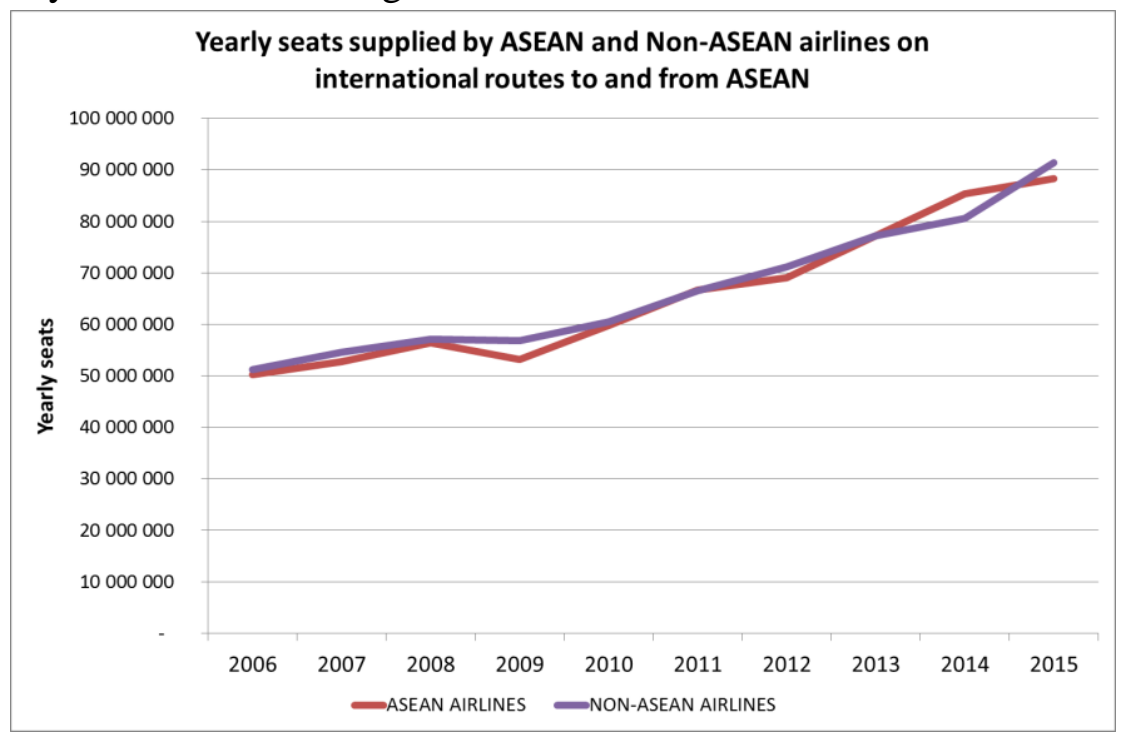

Fig 1 Yearly seats supplied by ASEAN and non-ASEAN airlines on international routes to and from ASEAN (data source from OAG database)

The situation is, however, significantly different on the air transport market between ASEAN and China. Firstly, this market is more dynamic: the total number of seats supplied was multiplied by 2.7 between 2006 and 2015 to reach 14.9 million seats. The

\footnotetext{
${ }^{3}$ The evolution of seats supplied being a proxy for measuring traffic evolution in terms of passengers transported
} 
growth was particularly high between 2010 and 2015 with 124\% more seats supplied over the period. Secondly, the market shares have evolved in favour of Chinese carriers: While the market shares of ASEAN airlines (in number of seats) on all international routes remained around 50\% between 2006 and 2015, they have decreased from 59\% to 48\% on routes between China and ASEAN during the same period (Figure 7). This loss of market share has been to the benefit of Chinese airlines for which the market share grew from $35 \%$ in 2006 to $51 \%$ in 2015.

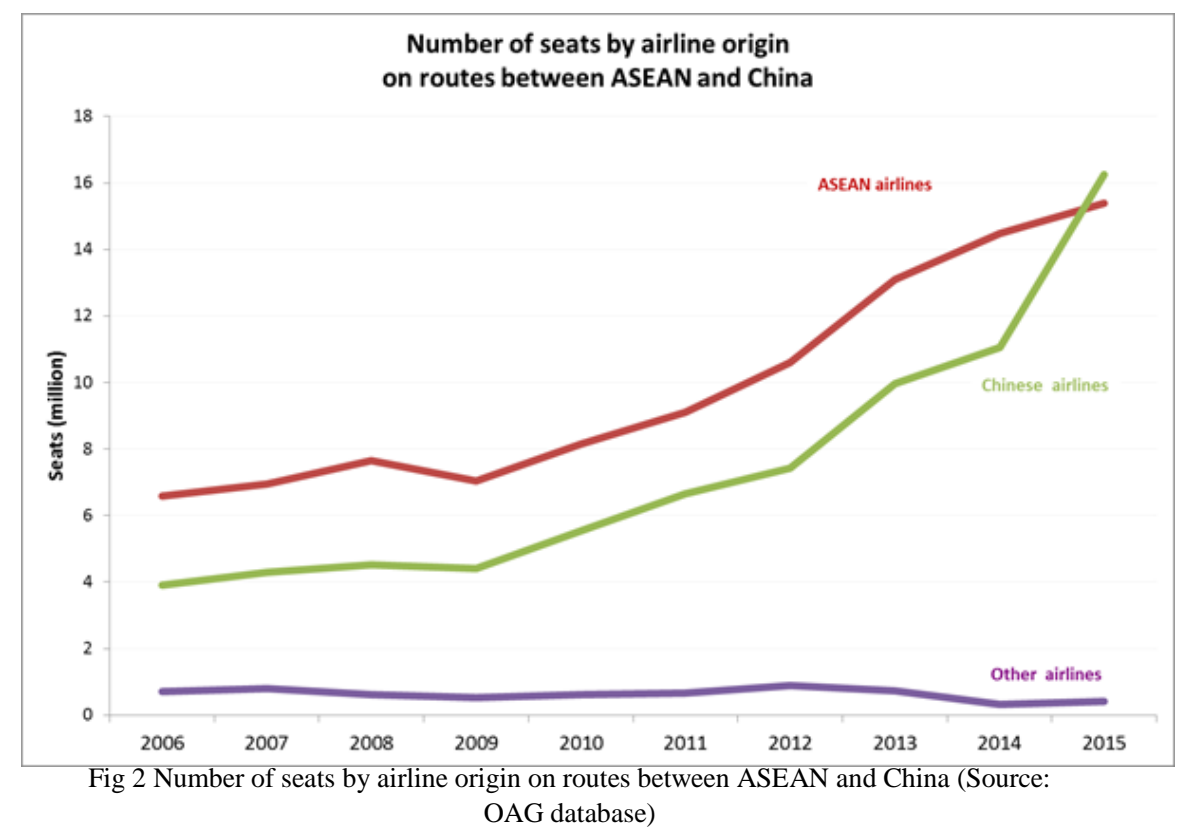

\section{ii) Routes and networks}

The strategy chosen by Chinese airlines to reach this strong growth of market shares was mainly to develop a more extended network than ASEAN airlines. If both ASEAN and Chinese airlines have increased their number of routes operated between 2006 and 2015 , the network operated by Chinese airlines has far more developed during the period considered (Fig 3). Moreover, while there are around twice more ASEAN airlines than Chinese airlines operating on routes between China and ASEAN (Fig 5), the average number of routes operated per airline is dramatically higher for Chinese airlines than for ASEAN airlines (Fig 4). In 2015, 27 ASEAN airlines operated around 250 routes, while 15 Chinese airlines operate more than 370 routes.

Another element of interest is the proportion of routes operated by carriers from only one country, or by ASEAN and Chinese carriers: in 2015 routes operated only by Chinese carriers represent $52 \%$ of the total routes between China and ASEAN, routes operated only by ASEAN carriers represent $27 \%$, and routes operated by both represent $21 \%$. This is another indication of the dominance of Chinese carriers over the networks. 


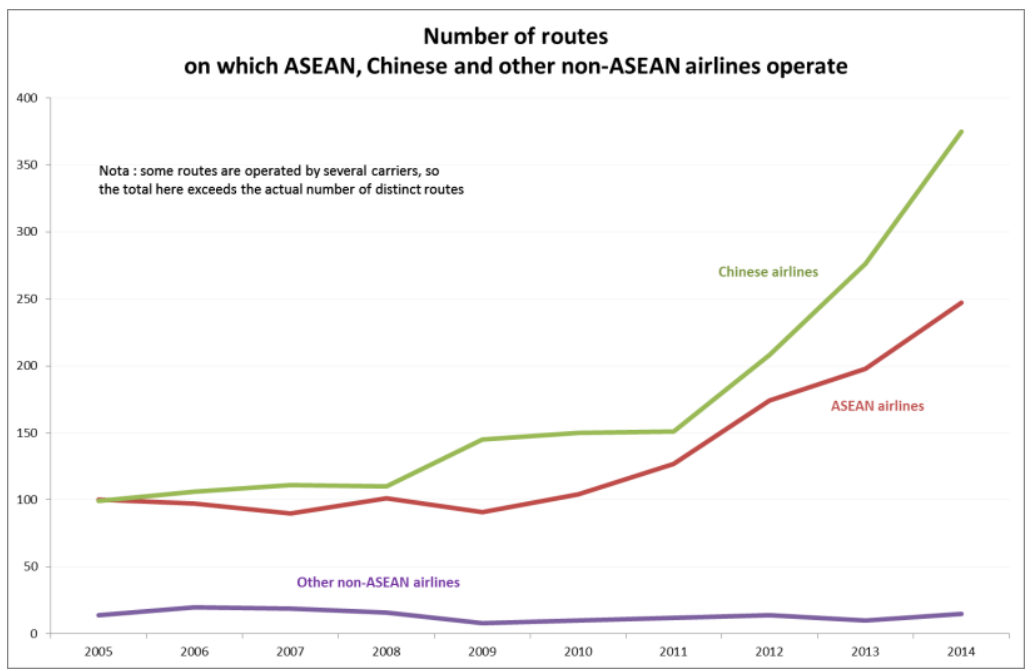

Fig 3 Number of routes on which ASEAN, Chinese and other non-ASEAN airlines operate (Source: OAG database)

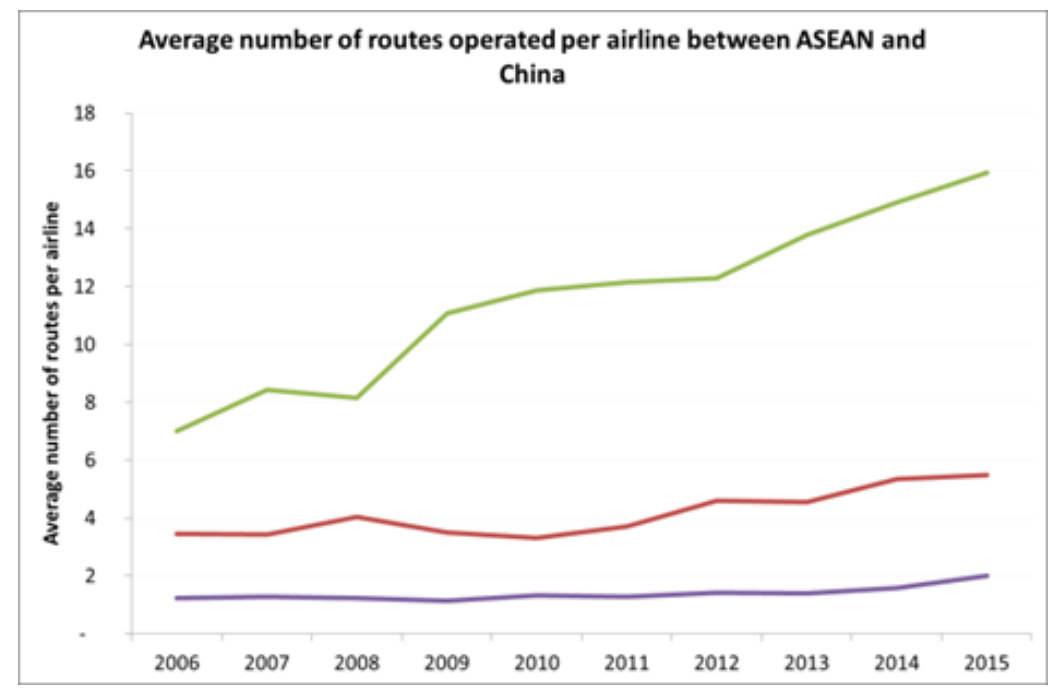

Fig 4 Average number of routes operated per airline between ASEAN and China (data source from OAG database)

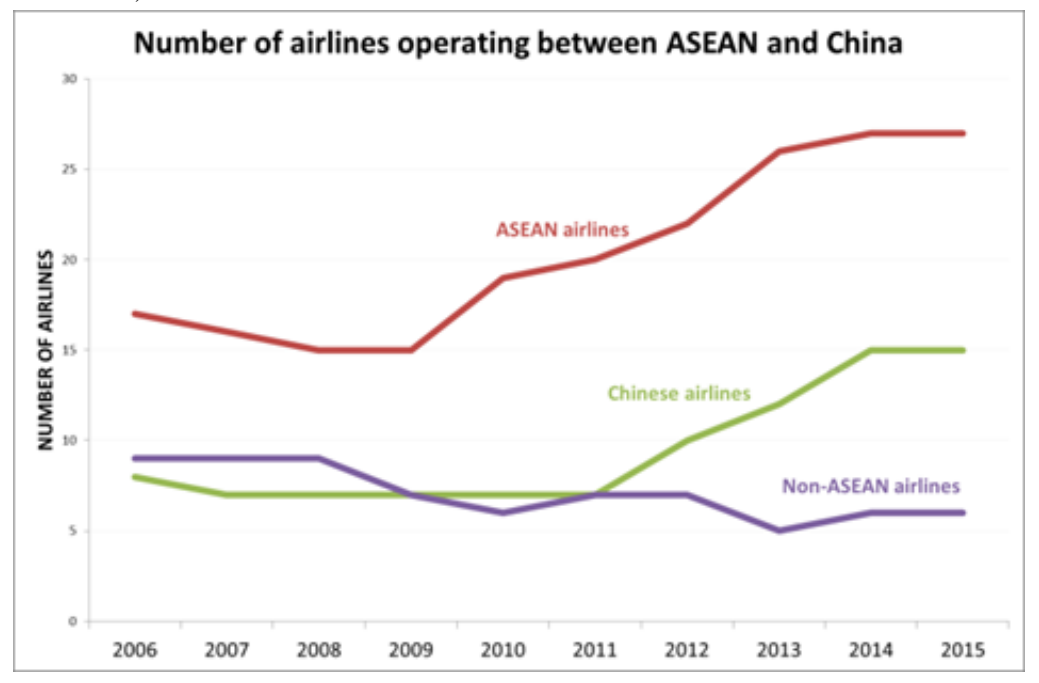

Fig 5 Number of airlines operating on routes between 2006 and 2015 (data source from OAG database) 
As an illustration, let us look at two airlines that developed their network during the period. We can see that China Southern Airlines opened routes from several cities in China to practically all countries in ASEAN, even if the effort was particularly concentrated in Guangzhou (China Southern is based there). On the other hand, the Thai airlines "Thai Air Asia" which is a low-cost airline (subsidiary of Air Asia) opened routes to several Chinese cities, especially in the southern and central part of China, but it is limited to start from Thailand (Bangkok, Chiang Mai, Krabi).

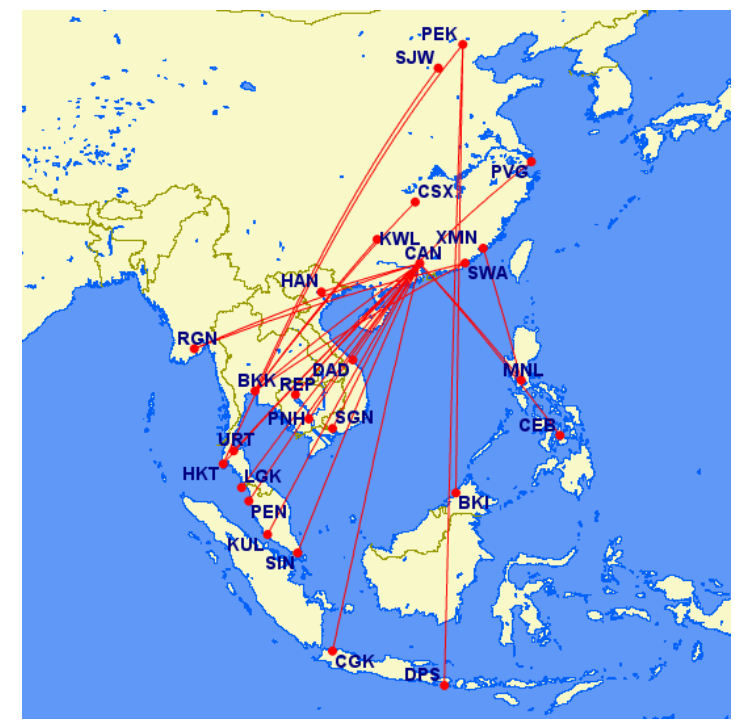

Fig 6 China Southern Airlines route network in 2010 (data source from OAG database, map with http://www.gcmap.com/)

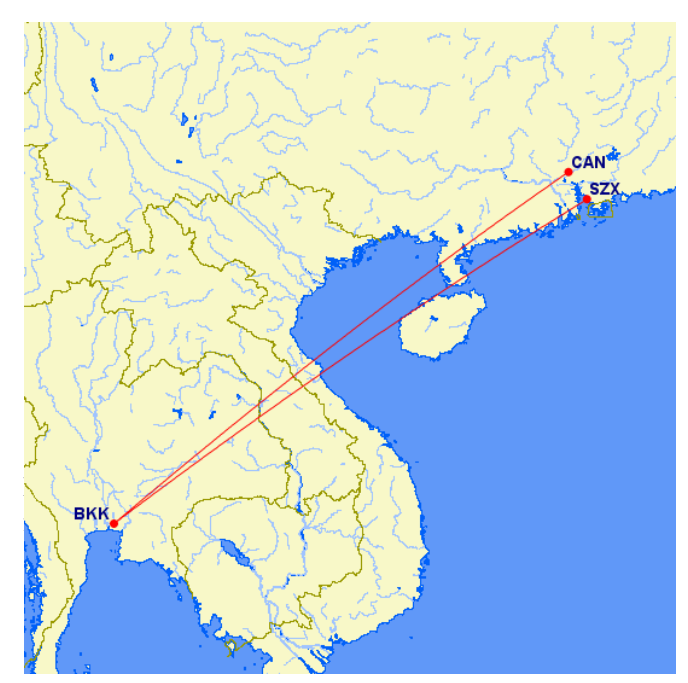

Fig 8 Thai Air Asia route network in 2010 (data source from OAG database, map with http://www.gcmap.com/)

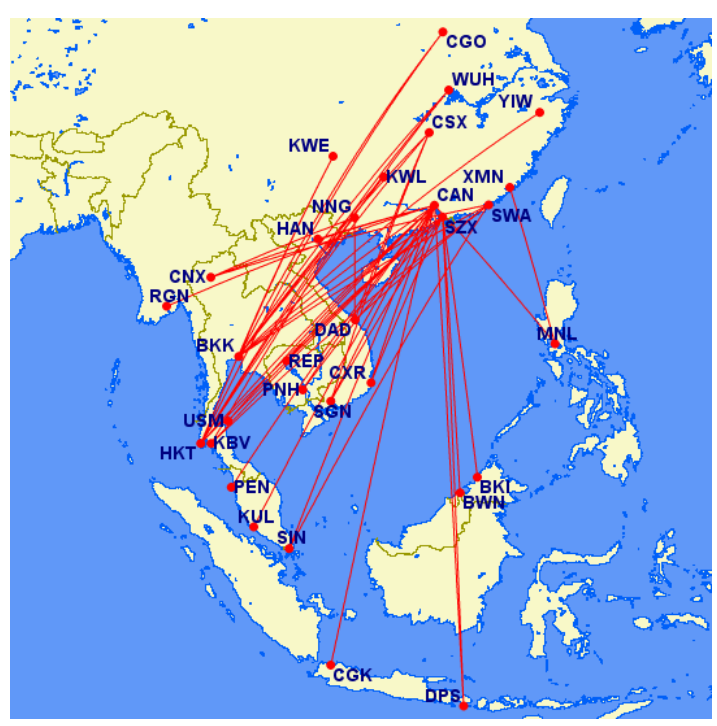

Fig 7 China Southern Airlines route network in 2015 (data source from OAG database, map with http://www.gcmap.com/)

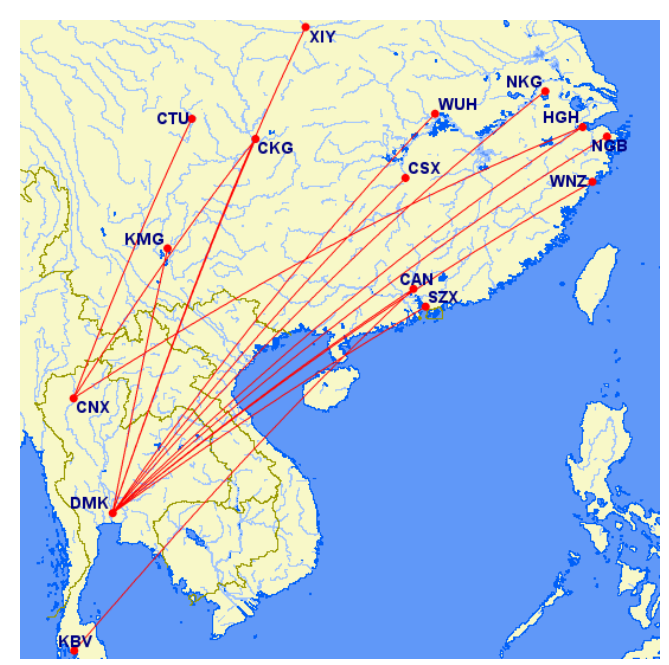

Fig 9 Thai Air Asia route network in 2015 (data source from OAG database, map with http://www.gcmap.com/)

\section{iii) Market entry and airlines}

Market attractiveness is strong: 16 new airlines have entered the ASEAN-China market between 2010 and 2015. It is interesting to stress that Chinese airlines were particularly attracted, since eight new Chinese airlines decided to operate in this market between 2010 
and 2015 (Fig 10). Entries in the market for new ASEAN airlines were rare since only one additional airline from Vietnam and one from Singapore entered the market.

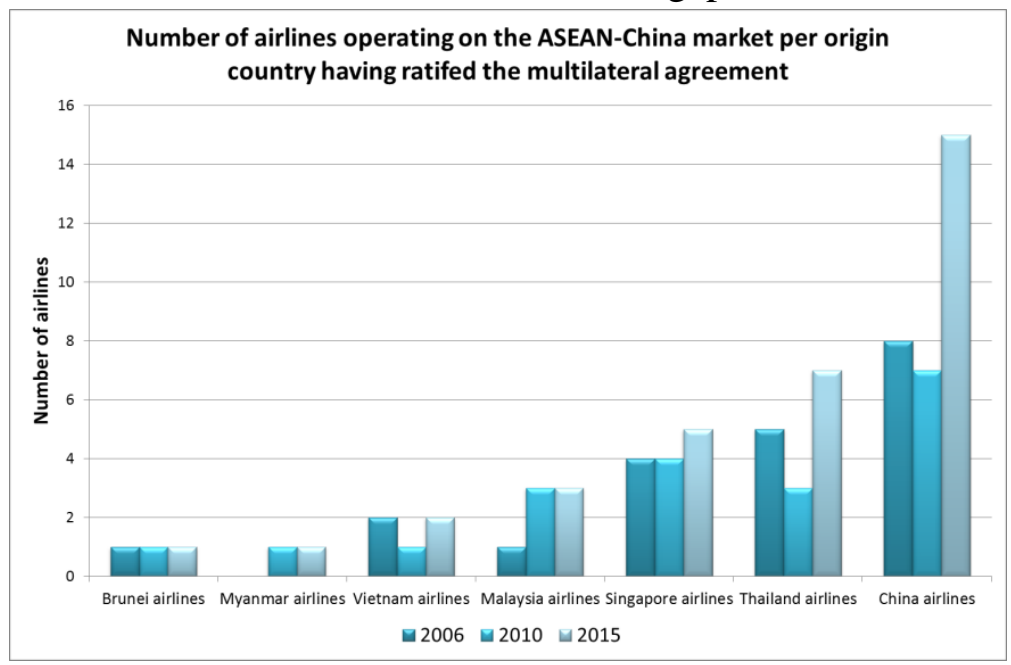

Fig 10 Number of airlines operating on the ASEAN-China market per origin country having ratified the multilateral agreement (data source from OAG database)

The exception was Thailand, where the number of Thai airlines strongly developed over the period with four more airlines operating on the market. The entry of new airlines on the market led to a decrease in the global market power of the fifteen more active airlines on the ASEAN-China market. While the top 15 airlines supplied $91 \%$ of the total seats in 2010 , this percentage decreased to $80 \%$ in 2015. Such a decrease of market power of the top 15 airlines is globally to the ASEAN airlines' disadvantage: the market share of ASEAN airlines belonging to the top 15 dropped from 52\% in 2010 to $37 \%$ in 2015 (fig 16).

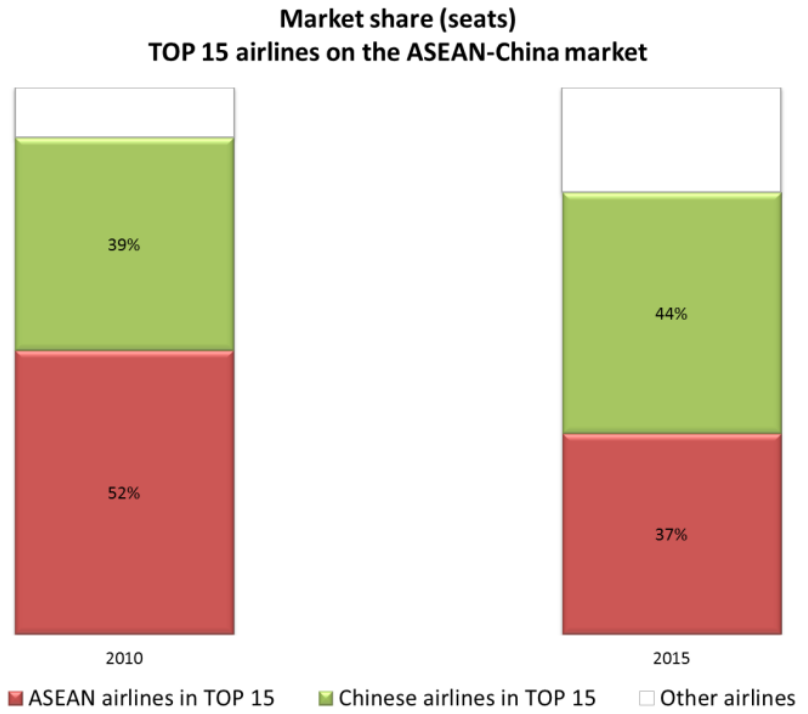

Fig 11 Market share (in number of seats) of Chinese and ASEAN airlines in the TOP 15 airlines on the ASEAN-China market (Source: OAG database) 


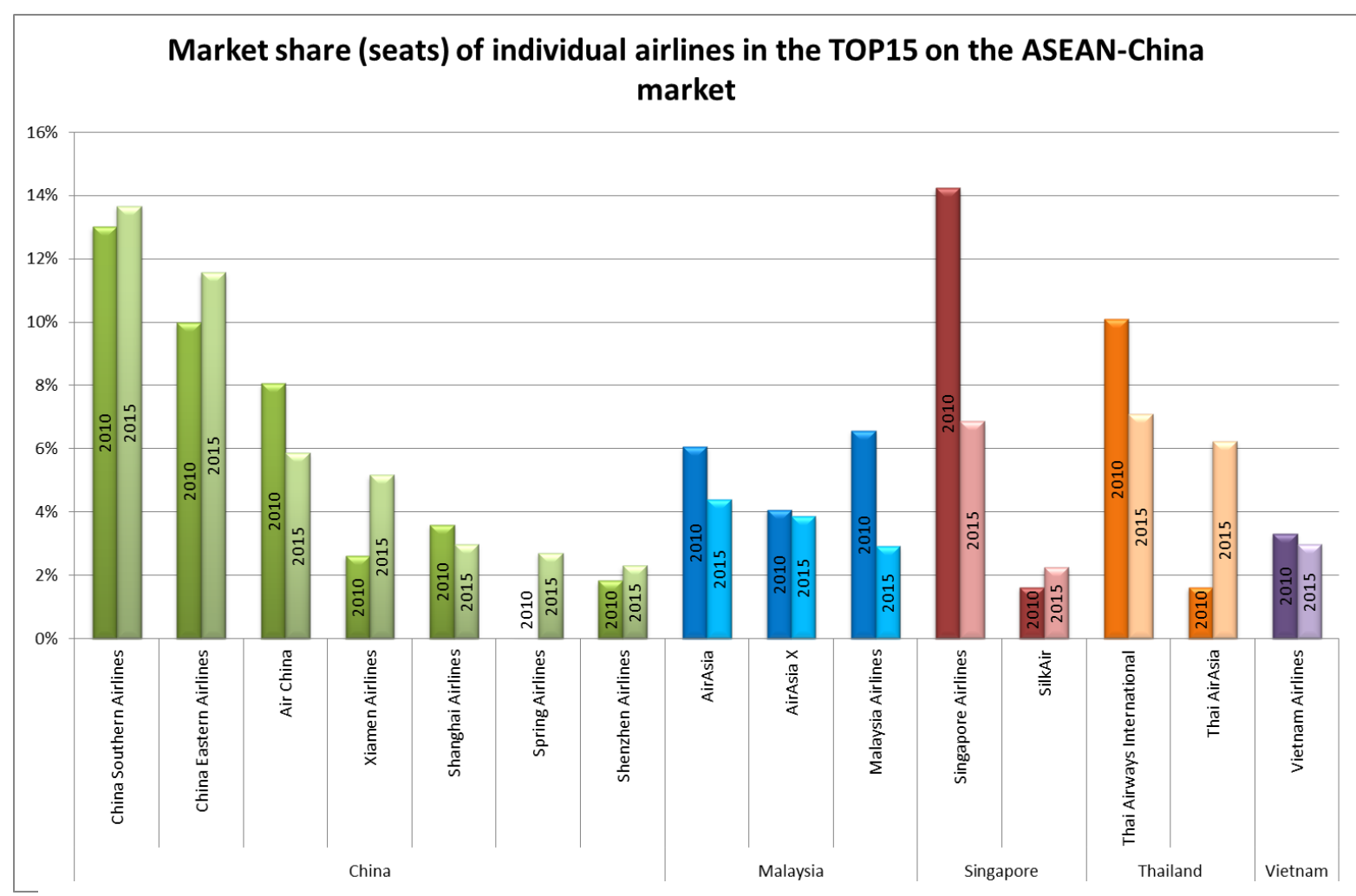

Fig 12 Market share (seats) of individual airlines in the TOP 15 on the ASEAN-China market (data source from OAG database)

Thai Air Asia and Silk Air are the only ASEAN airlines belonging to the top 15 which increased their market share between 2010 and 2015 (Figure 17). Thai Air Asia is a lowcost carrier, while Silk Air is the regional subsidiary of Singapore Airlines on short and medium-haul markets. The loss of market share was particularly strong for Singapore Airlines that dropped from a 14\% market share to a $7 \%$ market share over the period, which did not compensate for the increase of Silk Air by far.

There was an opposite trend for the Chinese airlines in the top 15 that generally tended to increase their market share. Only Air China and Shanghai airlines faced a market share reduction.

\section{Summary of Findings}

Our analysis shows that the traffic between ASEAN and China has grown tremendously since 2006, and even more since 2010. It appears that the market shares of airlines, in terms of available seats, have changed in favor of the Chinese airlines from $35 \%$ in 2006 to $51 \%$ in 2015 .

The case is especially clear on the markets from the six countries who signed the air service agreement with China during the period under consideration, liberalizing the 3rd and 4th freedom traffic between China and each country. This unbalance is significant in terms of seats offered, but even more in terms of routes opened and network development. The Chinese airlines operated nearly 200 routes in 2015 (from 120 in 2010), compared to 126 for ASEAN carriers.

One could argue that this evolution is due to the greater dynamism of Chinese carriers, but it is likely that the conditions of competition are also to blame: Chinese carriers can develop their networks from anywhere in China to anywhere in ASEAN, while the 
ASEAN carriers can only start from their country of origin. Each individual Chinese carrier has therefore more opportunities for network growth on profitable routes, and can benefit from economies of scope over the network.

This particular agreement therefore highlights the need for ASEAN to exercise caution when liberalizing new markets while the internal ASEAN market is still not liberalized.

\section{Discussion}

Following liberalization, air traffic demand in ASEAN will increase. We show in our analysis that as a consequence of traffic increase, national GDP is expected to grow yearly depending on the country, from $1 \%$ (Cambodia) to $6.1 \%$ (The Philippines). The magnitude of the impact depends on the tourism development expectation as well as on the contribution of tourism to GDP. The expected impacts will not be homogenous over the different countries: they depend on the socio-economic characteristics of the region where the airport is located. The analysis indicates that the economic benefits of air transport liberalization are non-negligible for the ASEAN countries. However, these positive economic impacts could be narrowed due to saturation problems at some airports, leading to losses in potential air traffic in some countries. To benefit fully from air transport liberalization, ASEAN countries should carefully consider their issues with airport congestion.

In addition to that, ASEAN airlines also face possible competition distortion due to multilateral agreements with third countries, as is shown by the case of the ASEAN-China agreement. In particular, two elements are missing in ASEAN: there is no real possibility today of having ASEAN carriers with traffic rights all over the region, and the existing national carriers do not have such extended traffic rights either. Impatience to sign agreements now with outside partners can place national airlines at a disadvantage as long as traffic rights are not liberalized inside ASEAN.

If we look closely at the case of the six ASEAN countries concerned so far with the horizontal agreement with China, we see contrasted situations, but globally the Chinese airlines benefit much more from the agreement, which is again very clear in terms of network development (50\% of routes in 2015 operated by Chinese carriers only).

By doing so, they gain a first mover advantage that may give them a competitive edge, and it is likely that the unbalance observed will only worsen over time, as long as the ASEAN carriers are limited in their development. While the traffic increase is so far beneficial to the passengers on both sides, the potential reduction in competition between carriers may be a bad thing in the long run, especially if the situation endures.

\section{Implications and recommendations}

Considering this situation, it would be advisable to move forward with the liberalization process, including in it the concept of ASEAN carriers, able to operate anywhere in the area. This would indeed set the balance right between ASEAN and partner states carriers before the latter become too powerful in the region, and it would enable ASEAN carriers to consolidate and to develop by accessing new markets. Some ASEAN airlines may be able to benefit more from this than others, but it would be better for them than having 
foreign carriers take the lead in the region. From a competitive point of view, and from the point of view of the passenger, it would also be preferable to have more competition between carriers of several countries than to have only a few carriers on most markets. So far, final steps, leading to an ASEAN Single Aviation Market (ASAM) similar to the Single European Aviation Market, still need to be taken, but are slow to come, partly because some countries are reluctant to move forward. The date at which the freedoms up to the ninth freedom right will be liberalized is hence not yet defined.

Opening all the freedoms to other ASEAN Member States has two main consequences: the first is that ASEAN airlines will be able to operate traffic from any airport of any other ASEAN country, to any destination of ASEAN. The second consequence is that ASEAN airlines will be able to directly target international airports in ASEAN (other than the airports concerned by the MAAS and MALFPAS agreements), which have now reached the safety and technical standards required after the 5th freedom is liberalized.

Beyond the possibility to fly everywhere inside ASEAN, ASAM would include the liberalisation of ownership, control of airlines, and advances on the concept of ASEAN Community Carrier. If ASAM were completed, it would ultimately lead to an ASEAN airspace open to all ASEAN carriers, with unified competition rules.

To help ASEAN member states prepare for the future, some recommendations can be made:

- Robust and reliable air traffic data are required in order to evaluate more precisely the impact of the ASAM on economic variables such as economic growth, employment or trade, and to formulate forecasts. A sufficient granularity is essential: the segmentation of the traffic into domestic, intra-ASEAN and extraASEAN traffic is needed to reach a better understanding of the influence of the liberalization at the State and regional levels. Historical data is also needed in order to perform consistent and relevant economic analysis.

- Institutional design and standardization: the air traffic management systems are different across the countries. Certain air traffic management systems have reached sufficient standards but others are still improving. Moreover, the slot allocation process is different and (especially for the congested airports) needs to be clarified and stated in order to allow entry for other airlines at congested airports.

- Design of a coherent competition policy. Liberalization will benefit the air transport market provided that conditions are in place to allow fair competition. The main issue will be to make sure that the conditions are satisfied to allow entry and to prevent any incumbent behaviour against competition development (abuse of dominant position).

\section{Conclusions}

Our analysis shows that the regional air transport liberalization should benefit the ASEAN airlines and the ASEAN countries, but not in a homogeneous way, depending on the socio-economic conditions of each region and the contribution of tourism to its economy, 
without forgetting that airport saturation can be a limiting factor to traffic growth.

Nevertheless, with the signature of external liberalizing treaties with partner states, ASEAN airlines are likely to face competition distortion, as is shown by the case of the ASEAN-China agreement, because of traffic rights unbalances between ASEAN airlines and Chinese airlines, in favor of the later.

The implications are that ASEAN countries should proceed with the liberalization process, in order to obtain the full benefits or liberalization and give their own airlines the best chances in the competitive markets to and from ASEAN. 


\section{References}

10th ASEAN Transport Ministers Meeting. 2004. '2004 ACTION PLAN FOR ASEAN AIR TRANSPORT INTEGRATION AND LIBERALIZATION, ADOPTED IN PHNOM PENH, CAMBODIA 23 $\begin{array}{llll}\text { NOVEMBER } & 2004 & & \\ & & & \end{array} 2004$. https://cil.nus.edu.sg/rp/pdf/2004\%20Action\%20Plan\%20for\%20ASEAN\%20Air\%20Transport $\% 20$ Integration \%20and\%20Liberalization-pdf.pdf.

Abate, Megersa. 2016. 'Economic Effects of Air Transport Market Liberalization in Africa'. Transportation Research Part A: Policy and Practice 92 (October): 326-37. https://doi.org/10.1016/j.tra.2016.06.014.

ASEAN. 2017. 'ASEAN TRANSPORT INSTRUMENTS AND STATUS OF RATIFICATION'. 2017. http://asean.org/storage/2017/10/Ratification-status-Transport-Agreement-as-of-Sept17.pdf. 2018. 'ASEANstats'. ASEANstats. 2018. https://www.aseanstats.org/.

Burghouwt, Guillaume, and Jaap G. de Wit. 2015. 'In the Wake of Liberalisation: Long-Term Developments in the EU Air Transport Market'. Transport Policy, Air Transport Economics, 43 (October): 104-13. https://doi.org/10.1016/j.tranpol.2015.05.006.

Dobruszkes, Frédéric. 2009. 'Does Liberalisation of Air Transport Imply Increasing Competition? Lessons from the European Case'. Transport Policy $16 \quad$ (1): 29-39. https://doi.org/10.1016/j.tranpol.2009.02.007.

Dobruszkes, Frédéric, and Véronique Mondou. 2013. 'Aviation Liberalization as a Means to Promote International Tourism: The EU-Morocco Case'. Journal of Air Transport Management 29 (June): 23-34. https://doi.org/10.1016/j.jairtraman.2013.02.001.

ECORYS. 2012. 'Provision of a Consultancy Study for EASA: Economic Impact of the ASEAN Single Aviation Market'.

FU, XIAOWEN, TAE HOON OUM, and ANMING ZHANG. 2010. 'Air Transport Liberalization and Its Impacts on Airline Competition and Air Passenger Traffic'. Transportation Journal 49 (4): 2441.

Goetz, Andrew R., and Timothy M. Vowles. 2009. 'The Good, the Bad, and the Ugly: 30 Years of US Airline Deregulation'. Journal of Transport Geography, Airline Industry Liberalization, 17 (4): 251-63. https://doi.org/10.1016/j.jtrangeo.2009.02.012.

IATA. 2007. 'Airline Liberalisation'. IATA ECONOMICS BRIEFING No.7.

IMF. 2018. 'IMF Data'. IMF. 2018. http://www.imf.org/en/Data.

InterVISTAS-ga. 2006. 'The Economic Impact of Air Service Liberalization'. http://www.intervistas.com/downloads/Economic_Impact_of_Air_Service_Liberalization_Final _Report.pdf.

Jankiewicz, Jacek, and Sonia Huderek-Glapska. 2016. 'The Air Transport Market in Central and Eastern Europe after a Decade of Liberalisation - Different Paths of Growth'. Journal of Transport Geography, Air transport liberalisation and airline network dynamics: Investigating the complex relationships, 50 (January): 45-56. https://doi.org/10.1016/j.jtrangeo.2015.06.002.

Laplace, I., N. Lenoir, E. Malavolti, and C. Roucolle. 2015. 'Provision for Consultancy Study on the Economic Impact of the ASEAN Single Aviation Market'. ASEAN Air Transport Integration Project.

Laplace, I., and E. Malavolti. 2016. 'Air Traffic Development in ASEAN: An Airport Capacity Analysis'. In . WCTR 2016 Shanghai.

Ministry of commerce, People's Republic of China. 2018. 'MINISTRY OF COMMERCE, PEOPLE'S REPUBLIC OF CHINA'. 2018. http://english.mofcom.gov.cn/.

Njoya, Eric Tchouamou, Panayiotis Christidis, and Alexandros Nikitas. 2018. 'Understanding the Impact of Liberalisation in the EU-Africa Aviation Market'. Journal of Transport Geography 71 (July): 161-71. https://doi.org/10.1016/j.jtrangeo.2018.07.014.

'OAG Analyser'. 2008. April 2008. https://analytics.oag.com/analyser-client/home.

Olariaga, Oscar Díaz, and José F. Zea. 2018. 'Influence of the Liberalization of the Air Transport Industry on Configuration of the Traffic in the Airport Network'. Transportation Research Procedia, XIII Conference on Transport Engineering, CIT2018, 33 (January): 43-50. 
https://doi.org/10.1016/j.trpro.2018.10.074.

Oliveira, Alessandro V. M., Gui Lohmann, and Tiago G. Costa. 2016. 'Network Concentration and Airport Congestion in a Post De-Regulation Context: A Case Study of Brazil 2000-2010'. Journal of Transport Geography, Air transport liberalisation and airline network dynamics: Investigating the complex relationships, 50 (Supplement C): 33-44. https://doi.org/10.1016/j.jtrangeo.2015.01.001. Warnock-Smith, David, and Peter Morrell. 2008. 'Air Transport Liberalisation and Traffic Growth in Tourism-Dependent Economies: A Case-History of Some US-Caribbean Markets'. Journal of Air Transport Management 14 (2): 82-91. https://doi.org/10.1016/j.jairtraman.2008.02.001. 


\section{Annexes}

\section{Annex 1: Lao PDR}

Database building

Air passengers per airport are provided by the Civil Aviation of Lao PDR for the period 2004-2013. The number of international tourists is provided for the whole period 20042013 by the Lao PDR Ministry of tourism. The data related to GDP and to the population are collected for the period 2004-2013 on the World Bank statistics website. No regional GDP has been provided or found on the publicly available data.

\section{Estimation results of equation 1}

Regional GDP $=\alpha \times$ Passenger number $+\beta \times$ regional fixed effect $+\gamma \times$ yearly fixed effect $+\mu$

\section{Equation 1}

\begin{tabular}{llll} 
Variable & Parameter Estimates & t Value & Approx Pr $>|t|$ \\
\hline $\begin{array}{l}\text { Passengers }(\alpha) \\
\text { Yearly fixed effects }\end{array}$ & 0.193673 & 8.06 & $<.0001$ \\
2010 Fixed effect $(\tau)$ & 85.19865 & 2.37 & 0.0234 \\
\hline
\end{tabular}

Table 3 Regression of GDP on Passenger number - Result of estimations for Lao PDR

A $\operatorname{Pr}>|t|$ lower than 0.1 indicates that the estimated coefficient can be considered as non-zero.

Estimation results of equation 2

Passenger number $=\delta \times$ tourist number $+\eta \times$ percentage of internatio nal passengers

$+\tau \times$ regional fixed effect $+v \times$ yearly fixed effect $+\psi$

Equation 2

\begin{tabular}{lccc} 
Parameter & Parameter Estimates & $\mathrm{t}$ Value & Approx $\operatorname{Pr}>|\mathrm{t}|$ \\
\hline $\begin{array}{l}\text { Tourist number }(\delta) \\
\begin{array}{l}\text { Percentage of international } \\
\text { passengers }(\eta)\end{array}\end{array}$ & 0.162301 & 4.21 & 0.0002 \\
\hline
\end{tabular}

Table 4 Regression of Passenger numbers on the number of tourists and percentage of international passengers - Result of estimations for Lao PDR

A $\operatorname{Pr}>|t|$ lower than 0.1 indicates that the estimated coefficient can be considered as non-zero. 


\section{Annex 2: Myanmar}

Database building

Air passengers per airport are provided by the Civil Aviation of Myanmar for the period 2004-2013. The number of international tourists has been provided by the Myanmar Ministry of Tourism for the period 2002-2013. Regional GDP has been provided by the Myanmar Ministry of Economy for the period 2004-2013. The data related to the population are collected for the period 2003-2013 on the World Bank statistics website.

Estimation results of equation 1

Regional GDP $=\alpha \times$ Passenger number $+\beta \times$ Provincefixed effect $+\gamma \times$ yearly fixed effect $+\mu$ Equation 1

\begin{tabular}{llll} 
Variable & $\begin{array}{l}\text { Parameter } \\
\text { Estimates }\end{array}$ & Approx \\
\hline Passengers $(\alpha)$ & 568.6702 & 2.27 & 0.0275 \\
Province fixed effects $(\beta)$ & & & \\
Ayeyarwaddy Region & 723042.9 & 1.95 & 0.0573 \\
Kachin State & -95382.4 & -0.28 & 0.7817 \\
Kayah State & 9808.954 & 0.03 & 0.9766 \\
Mandalay Region & referent Region & & \\
Mon State & 230424.2 & 0.69 & 0.4914 \\
Naypyidaw Council & 68859.94 & 0.18 & 0.8545 \\
Rakhine State & 7038.875 & 0.02 & 0.9836 \\
Sagaing Region & 555964.9 & 1.67 & 0.1011 \\
Shan State & -230594 & -0.57 & 0.5745 \\
Tanintharyi Region & 146770.6 & 0.41 & 0.6823 \\
Yangon Region & -275431 & -0.39 & 0.6945 \\
\hline
\end{tabular}

Table 5 Regression of GDP on Passenger number - Result of estimations for Myanmar A $\operatorname{Pr}>|t|$ lower than 0.1 indicates that the estimated coefficient can be considered as non-zero. 
Estimation results of equation 2

Passenger number $=\delta \times$ tourist number $+\eta \times$ percentage of internatio nal passengers $+\tau \times$ Province fixed effect $+v \times$ yearly fixed effect $+\psi$ Equation 2

\begin{tabular}{llll} 
& Parameter & & Approx \\
Parameter & Estimates & t Value & Pr $>|t|$ \\
\hline Tourist number $(\delta)$ & 0.042662 & 0.94 & 0.3530 \\
Percentage of international passengers $(\eta)$ & 119.4533 & 1.43 & 0.1605 \\
Province fixed effects $(\tau)$ & & & \\
Ayeyarwaddy Region & -136.332 & -0.23 & 0.8222 \\
Kachin State & 214.6182 & 0.40 & 0.6913 \\
Kayah State & -100.028 & -0.19 & 0.8531 \\
Mandalay Region & referent province & & \\
Mon State & -97.2058 & -0.18 & 0.8572 \\
Naypyidaw Council & -581.871 & -0.83 & 0.4111 \\
Rakhine State & 173.4342 & 0.32 & 0.7482 \\
Sagaing Region & -44.0698 & -0.08 & 0.9350 \\
Shan State & 833.2142 & 1.55 & 0.1274 \\
Tanintharyi Region & 402.4282 & 0.75 & 0.4574 \\
Yangon Region & 2339.959 & 5.70 & $<.0001$ \\
\hline
\end{tabular}

Table 6 Regression of Passenger numbers on the number of tourists and percentage of international passengers - Result of estimations for Myanmar

A $P r>|t|$ lower than 0.1 indicates that the estimated coefficient can be considered as non-zero. 


\section{Annex 3: The Philippines}

Database building

Air passengers per airport are provided by Filipino Civil Aviation for the period 20042013. The number of international tourists is provided by the Filipino Statistics Authority for the period 2004-2013. The data related to GDP and to the population are collected for the period 2004-2013 on the World Bank statistics website. No regional GDP has been provided or found on the publicly available data.

\section{Estimation results of equation 1}

Regional GDP $=\alpha \times$ Passenger number $+\beta \times$ City fixed effect $+\gamma \times$ yearly fixed effect $+\mu$ Equation 1

\begin{tabular}{|c|c|c|c|}
\hline Variable & Parameter Estimates & t Value & Approx $\operatorname{Pr}>|t|$ \\
\hline Passengers $(\alpha)$ & 0.15634 & 1.97 & 0.0510 \\
\hline \multicolumn{4}{|l|}{ Yearly fixed effect $(\gamma)$} \\
\hline 2009 fixed effect & -1876.86 & -6.59 & $<.0001$ \\
\hline \multicolumn{4}{|l|}{ City fixed effects $(\beta)$} \\
\hline Ilocos region & 1120.809 & 3.40 & 0.0009 \\
\hline Cagayan Valley & 812.1294 & 2.46 & 0.0152 \\
\hline Central Luzon region & 2188.348 & 6.63 & $<.0001$ \\
\hline Calabarzon & 2654.926 & 8.05 & $<.0001$ \\
\hline Mimaropa & 555.7136 & 1.63 & 0.1056 \\
\hline Caraga & 614.0461 & 1.86 & 0.0658 \\
\hline Bicol region & 1167.504 & 3.51 & 0.0006 \\
\hline Westen Visayas & 850.4839 & 1.72 & 0.0882 \\
\hline Central Visayas & 1383.844 & 4.11 & $<.0001$ \\
\hline Eastern Visayas & 957.8738 & 2.90 & 0.0044 \\
\hline Zamboanga peninsula & 744.2647 & 2.22 & 0.0280 \\
\hline Northern Mindanao & 745.8222 & 2.07 & 0.0403 \\
\hline Davao Region & \multicolumn{3}{|l|}{ REFERENT REGION } \\
\hline Metro Manila & -547.647 & -0.35 & 0.7302 \\
\hline
\end{tabular}


Autonomous region of Muslim

Mindanao

817.0585

$2.48 \quad 0.0146$

Table 7 Regression of GDP on Passenger number - Result of estimations for the Philippines

A $P r>|t|$ lower than 0.1 indicates that the estimated coefficient can be considered as non-zero.

Estimation results of equation 2

Passenger number $=\delta \times$ tourist number $+\eta \times$ percentage of internatio nal passengers

$+\tau \times$ City fixed effect $+v \times$ yearly fixed effect $+\psi$

Equation 2

\begin{tabular}{llcc} 
Variable & Parameter Estimates & $\mathrm{t}$ Value & Approx Pr $>|\mathrm{t}|$ \\
\hline Tourist number $(\delta)$ & 0.375401 & 1.08 & 0.2841 \\
Percentage of international passengers $(\eta)$ & 68.74863 & 1.45 & 0.1498 \\
Yearly fixed effect $(v)$ & & & \\
2009 fixed effect & 2830.756 & 1.30 & 0.1951
\end{tabular}

City fixed effect $(\tau)$

Ilocos region

Cagayan Valley

Central Luzon region

Calabarzon

Mimaropa

Caraga

Bicol region

Westen Visayas

Central Visayas

Eastern Visayas

Zamboanga peninsula

Northern Mindanao

Davao Region

Metro Manila
$-760.326$

$-1129.99$

$-1284.77$

$-1174.69$

$-96.3424$

$-864.323$

$-660.137$

3378.263

$-291.453$

$-970.472$

$-472.85$

631.2265

REFERENT REGION

18438.96

8.09

$<.0001$ 
Economic impacts of the ASEAN single aviation market

$\begin{array}{llll}\text { Autonomous region of Muslim Mindanao } & -1127.75 & -0.50 & 0.6212\end{array}$

Table 8 Regression of Passenger numbers on the number of tourists and percentage of international passengers - Result of estimations for the Philippines

A $\operatorname{Pr}>|t|$ lower than 0.1 indicates that the estimated coefficient can be considered as non-zero. 


\section{Annex 4: Vietnam}

Database building

Air passengers per airport are provided by the Civil Aviation of Vietnam for the period 2009-2013. The number of international tourists is collected into the ASEAN statistics for the period 2009-2012. This number for 2013 is provided by the Ministry of Tourism of Vietnam. The data related to GDP and to the population are collected for the period 2009-2013 on the World Bank statistics website. No regional GDP has been provided or found on the publicly available data.

\section{Estimation results of equation 1}

Regional GDP $=\alpha \times$ Passenger number $+\beta \times$ Provincefixed effect $+\gamma \times$ yearly fixed effect $+\mu$ Equation 1

\begin{tabular}{|c|c|c|c|}
\hline Variable & Parameter Estimates & t Value & Approx $\operatorname{Pr}>|t|$ \\
\hline Passengers $(\alpha)$ & 0.021558 & 1.64 & 0.1070 \\
\hline \multicolumn{4}{|c|}{ Yearly fixed effect ( $\beta$ ) } \\
\hline 2012 fixed effect & 138.8078 & 3.30 & 0.0017 \\
\hline \multicolumn{4}{|c|}{ Province fixed effects $(\gamma)$} \\
\hline ba ria vung tau & 130.8839 & 1.64 & 0.1075 \\
\hline binh dinh & 201.8583 & 2.52 & 0.0147 \\
\hline ca mau & 164.4651 & 2.06 & 0.0441 \\
\hline can tho & 159.5311 & 2.00 & 0.0509 \\
\hline da nang & 9.170871 & 0.08 & 0.9330 \\
\hline dak lak & 245.9613 & 3.05 & 0.0035 \\
\hline dien bien phu & 51.14737 & 0.64 & 0.5244 \\
\hline gia lai & 175.1495 & 2.18 & 0.0334 \\
\hline haiphong & referent province & & \\
\hline hanoi & 825.5103 & 4.48 & $<.0001$ \\
\hline ho chi minh & 847.4863 & 3.35 & 0.0015 \\
\hline khanh hoa & 118.4319 & 1.41 & 0.1650 \\
\hline kien giang & 229.4856 & 2.84 & 0.0063 \\
\hline
\end{tabular}




\begin{tabular}{lccc} 
lam dong & 153.5686 & 1.91 & 0.0617 \\
nghe an & 413.5995 & 4.96 & $<.0001$ \\
quang binh & 101.4132 & 1.27 & 0.2099 \\
quang nam & 201.4364 & 2.52 & 0.0145 \\
tay ninh & 141.8866 & 1.78 & 0.0811 \\
thua thien hue & 161.5739 & 2.02 & 0.0485 \\
\hline
\end{tabular}

Table 9 Regression of GDP on Passenger number - Result of estimations for Vietnam A Pr $>|t|$ lower than 0.1 indicates that the estimated coefficient can be considered as non-zero.

\section{Estimation results of equation 2}

Passenger number $=\delta \times$ tourist number $+\eta \times$ percentage of internatio nal passengers $+\tau \times$ provincefixed effect $+v \times$ yearly fixed effect $+\psi$ Equation 2

\begin{tabular}{|c|c|c|c|}
\hline & Parameter & & Approx \\
\hline Parameter & Estimates & t Value & $\operatorname{Pr}>|t|$ \\
\hline Tourist number $(\delta)$ & 0.096908 & 1.29 & 0.2009 \\
\hline Percentage of international passengers $(\eta)$ & -2433.05 & -5.97 & $<.0001$ \\
\hline \multicolumn{4}{|l|}{ Yearly fixed effect $(v)$} \\
\hline 2012 fixed effect & -233.215 & -0.45 & 0.6532 \\
\hline \multicolumn{4}{|l|}{ Province fixed effects $(\tau)$} \\
\hline ba ria vung tau & -591.06 & -0.48 & 0.6305 \\
\hline binh dinh & -426.987 & -0.35 & 0.7281 \\
\hline ca mau & -886.642 & -0.73 & 0.4712 \\
\hline can tho & -638.887 & -0.52 & 0.6032 \\
\hline da nang & 7523.722 & & \\
\hline dak lak & -75.3996 & -0.06 & 0.9510 \\
\hline dien bien phu & -861.55 & -0.71 & 0.4837 \\
\hline gia lai & -324.812 & -0.27 & 0.7914 \\
\hline
\end{tabular}




$\begin{array}{llll}\text { haiphong } & \text { referent province } & & \\ \text { hanoi } & 14084.36 & 10.88 & <.0001 \\ \text { ho chi minh } & 16231.91 & 13.18 & <.0001 \\ \text { khanh hoa } & 1041.725 & 0.85 & 0.3976 \\ \text { kien giang } & 16.62295 & 0.01 & 0.9892 \\ \text { lam dong } & -182.542 & -0.15 & 0.8818 \\ \text { nghe an } & 841.3854 & 0.69 & 0.4940 \\ \text { quang binh } & -654.59 & -0.54 & 0.5943 \\ \text { quang nam } & -780.545 & -0.64 & 0.5256 \\ \text { tay ninh } & -778.165 & -0.64 & 0.5269 \\ \text { thua thien hue } & -1478.39 & -1.21 & 0.2315\end{array}$

Table 101 Regression of Passenger numbers on the number of tourists and percentage of international passengers - Result of estimations for Vietnam

A $\operatorname{Pr}>|t|$ lower than 0.1 indicates that the estimated coefficient can be considered as non-zero. 


\section{Annex 5: Cambodia}

Database building

Air passengers per airport are provided by Civil Aviation of Cambodia for the period 2004-2013. The number of international tourists is provided by Cambodian government for the whole period of analysis 2004-2013. The data related to GDP and to the population are collected for the period 2004-2013 on the World Bank statistics website. No regional GDP has been provided or found on the publicly available data.

\section{Estimation results of equation 1}

Regional GDP $=\alpha \times$ Passenger number $+\beta \times$ Urbanarea fixed effect $+\gamma \times$ yearly fixed effect $+\mu$ Equation 1

\begin{tabular}{llll} 
Variable & $\begin{array}{l}\text { Parameter } \\
\text { Estimates }\end{array}$ & t Value & $\begin{array}{l}\text { Approx } \\
\operatorname{Pr}>|t|\end{array}$ \\
\hline Passengers & 0.048007 & 3.54 & 0.0030 \\
Yearly fixed effect & & & \\
2009 fixed effect & 142.6412 & 1.76 & 0.0983 \\
Siem Reap fixed effect & -108.073 & -2.32 & 0.0347 \\
Phnom Penh & Referent airport & & \\
\hline Table 11 Regression of GDP & on Passenger number - Result of estimations for Cambodia \\
A Pr $>|t|$ lower than 0.1 indicates that the estimated coefficient can be considered as non-zero.
\end{tabular}

\section{Estimation results of equation 2}

Passenger number $=\delta \times$ tourist number $+\eta \times$ percentage of internatio nal passengers $+\tau \times$ urbanarea fixed effect $+v \times$ yearly fixed effect $+\psi$ Equation 2

\begin{tabular}{llll} 
& $\begin{array}{l}\text { Parameter } \\
\text { Estimates }\end{array}$ & t Value & $\begin{array}{l}\text { Approx } \\
\text { Pr }>|t|\end{array}$ \\
\hline Constant & 451.7519 & 0.47 & 0.6443 \\
Tourist number $(\delta)$ & 0.451947 & 2.30 & 0.0387 \\
Percentage of international passengers $(\eta)$ & -107.59 & -0.80 & 0.4386 \\
Yearly fixed effect $(v)$ & & & \\
2009 fixed effect & -2699.37 & -2.15 & 0.0510 \\
Siem Reap fixed effect $(\tau)$ & 564.0629 & 0.87 & 0.3986 \\
Phnom Pen & Referent airport & & \\
\hline
\end{tabular}

Table 12 Regression of Passenger numbers on the number of tourists and percentage of international passengers - Result of estimations for Cambodia

A $\operatorname{Pr}>|t|$ lower than 0.1 indicates that the estimated coefficient can be considered as non-zero. 
Economic impacts of the ASEAN single aviation market 